\title{
A kommunikáció nehézségei daganatos gyermekek szüleivel a palliatív ellátásra történő áttérés során
}

\author{
Nyirő Judit ${ }^{1}$ - Hauser Péter dr. ${ }^{2}$ - Zörgő Szilvia ${ }^{1}$ - Hegedüs Katalin dr. ${ }^{1}$ \\ Semmelweis Egyetem, Általános Orvostudományi Kar, ${ }^{1}$ Magatartástudományi Intézet, \\ ${ }^{2}$ II. Gyermekgyógyászati Klinika, Budapest
}

Bevezetés: A daganatos gyermekek betegséglefolyásának bizonyos pontjain kiemelten fontos a megfelelő kommunikáció az egészségügyi dolgozók részéről.

Célkitüzés: Annak vizsgálata, hogy a gyermekonkológiai ellátásban, a szülőkkel történő kommunikációban mikor és hogyan kerül bevezetésre a palliatív ellátás fogalma.

Módszer: 14 kérdésból álló strukturált interjú készítése a Magyar Gyermekonkológiai Hálózat orvosaival $(\mathrm{n}=22)$. A válaszok rendszerezése, kiértékelése induktív kódolással történt, az Atlas.ti 6.0 szoftver segítségével.

Eredmények: Interjúinkban a palliatív terápiára való áttérésnek általában egyszeri, a gyógyító lehetőségek kimerülése utáni közlése jellemző. Az orvosok többsége bevon a beszélgetésbe egy másik szakembert, lehetőleg pszichológust. A szóhasználatot tekintve vannak jellemzően használt és elkerült szavak, amelyek között előfordulnak egyértelműséget, önvédelmet és empátiát tükröző szavak/kifejezések. Legellentmondásosabb a halál, haldoklás kommunikációja. Következtetés: Magyarországon a gyermekkori palliatív ellátás kommunikációjának területén jelen vizsgálat volt az első felmérés. A vizsgálat megmutatta, hogy hazánkban is érzékelhető már a palliatív kommunikáció modern szemléletének jelenléte, azonban ennek elterjedése még több időt igényel.

Orv Hetil. 2017; 158(30): 1175-1181.

Kulcsszavak: gyermekonkológia, orvosi kommunikáció, palliatív ellátás

\section{Difficulties in communication with parents of pediatric cancer patients during the transition to palliative care}

Introduction: Adequate communication by medical personnel is especially important at certain points during the treatment of childhood cancer patients.

Aim: To investigate the timing and manner of communication with parents concerning the introduction of palliative care in pediatric oncology.

Method: Structured interviews, containing 14 questions, were carried out with physicians working in pediatric oncol$\operatorname{ogy}(\mathrm{n}=22)$. Codes were generated inductively with the aid of Atlas.ti 6.0 software.

Results: Interviews show a tendency of a one-step transition to palliative care following curative therapy. Another expert is usually involved in communication, most likely a psychologist. Regarding communication, there are expressions utilized or avoided, such as expressing clarity, self-defense and empathy. The communication of death and dying was the most contradictory.

Conclusion: This was the first investigation regarding communication in pediatric palliative care in Hungary. Our results show that a modern perspective of palliative communication is present, but necessitates more time to become entrenched.

Keywords: pediatric oncology, medical communication, palliative care

Nyirő J, Hauser P, Zörgő Sz, Hegedűs K. [Difficulties in communication with parents of pediatric cancer patients during the transition to palliative care]. Orv Hetil. 2017; 158(30): 1175-1181.

(Beérkezett: 2017. május 26.; elfogadva: 2017. június 15.) 
Egy szülő számára az egyik legnehezebb helyzet azt megtudni, hogy a gyermeke gyógyíthatatlan beteg. Ennél még nehezebb azzal szembesülnie, hogy a gyermek valószínúleg belátható időn belül meghal. Mindez az orvos és a gyógyítóteam számára is kihívást jelent, hiszen legtöbbször már hosszú ideje kezelik a kis beteget, és mindent megtettek azért, hogy meggyógyítsák. Hogyan lehet megmondani a szülőnek, hogy a gyógyítás lehetőségei elfogytak? Kinek, mikor és hogyan kell kommunikálnia, hogy a fö cél a hátralevő időben elsősorban a palliáció, vagyis a fájdalom, a kínzó tünetek enyhítése lesz?

Napjainkban a gyermekkori rosszindulatú daganatos betegségekből várható végleges gyógyulási arány a fejlett országokban $80 \%$ felett van [1]. A gyermekonkológiában az elmúlt 40 évben észlelhető nagymértékű javulás ellenére sem lehet elfelejteni, hogy a gyermekek egy részénél továbbra is szükség van az életvégi, palliatív ellátásra. A gyermekgyógyászati palliatív ellátás standardjai (IMPaCCT) szerint a gyermekek palliatív ellátása a gyermek testének, lelkének és szellemének aktív, teljes gondozását jelenti, és magában foglalja a hozzátartozók támogatását is. A betegség diagnosztizálásakor veszi kezdetét, és attól függetlenül folytatódik, hogy a gyermek részesül-e a betegség gyógyítását célzó (kuratív) kezelésben. A gyermekgyógyászati palliatív ellátás célja a gyermekek és hozzátartozóik életminőségének javítása. Az egészségügyi személyzetnek fel kell mérnie a gyermekre háruló fizikai, pszichés és szociális terhelés mértékét, és enyhítenie kell azt. A hatékony palliatív ellátás széles körű, multidiszciplináris megközelítést igényel, amelyben a hozzátartozók is részt vesznek [2].

A világ országainak $65 \%$-ában gyermekkorban semmilyen palliatív ellátás (palliáció) nem létezik, noha 63/100 000 gyermek igényelne palliatív ellátást világszerte $[3,4]$. 2009-ben Fokvárosban született meg a gyermekek palliatív ellátáshoz való jogáról szóló deklaráció [5]. 2012-ben adott ki először az Egészségügyi Világszervezet (WHO) útmutatót a gyermekek gyógyszeres kezeléséről krónikus perzisztáló fájdalom esetén [6]. A haldokló gyermekek jogait csak 2014-ben nyilvánították ki [7]. Mindezek kapcsán Magyarországon is elindult egy szemléletváltás, amelynek részeként megkezdték múködésüket a gyermek palliatív ellátásra specializálódó intézmények és szervezetek [8].

A jelenleg elfogadott standard szerint a palliatív kezelésnek a potenciálisan halálos krónikus betegségek esetében már a diagnózis közlésekor el kell kezdődnie, a kuratív ellátással egyidejűleg, vele párhuzamosan. A beteg állapotának alakulása függvényében idővel dominánssá válhat a palliatív ellátás. Ebben a szemléletben a párhuzamos, palliatív kezelést egy erre szakosodott palliatív csapat végzi, amelyben palliatív orvos, nővér, pszichológus, lelki gondozó és szociális munkás vehet részt. Nemzetközi tapasztalatok alapján ez a struktúra jelentősen megkönnyíti az életvégi ellátás személyre szabott, kellően körültekintő végzését [2].
A palliatív ellátás kezdeti, a diagnózis közlésekor történő bevezetése a nemzetközi tapasztalatok alapján mind a felnőtt-, mind a gyermekellátás területén komoly nehézségekbe ütközik [9]. E nehézségek hátterében a megfelelően képzett palliatív szakemberek hiánya, az ellátást jelenleg végző egészségügyi személyzet nem megfelelő szemlélete és a betegek, illetve hozzátartozóik gyógyíthatósággal kapcsolatos fokozott elvárásából fakadó problémák is állhatnak [10].

Magyarországon egyéves életkor felett a gyermekellátás területén leginkább a gyermekonkológiai ellátás során kell szembesülni a gyermekhalállal. Hazánkban először Polcz Alaine vetette fel ezt a problémát könyveiben [11]. Az elmúlt évtizedben egyre terjedő képzéseknek is köszönhető, hogy a gyermekonkológiai ellátásban részt vevő egészségügyi ellátószemélyzetet tekinthetjük a leginkább felkészülttnek a palliatív ellátás terén: tudatosan használják a palliatív ellátás fogalmát és vallják ennek szükségességét. Jelen tanulmányunk célja volt megvizsgálni azt a kérdést, hogy a hazai gyermekonkológiai ellátásban a szülőkkel történő kommunikációban milyen esetekben, az ellátás mely szakában és milyen formában kerül bevezetésre a palliatív ellátás fogalma.

\section{Módszer}

A palliatív ellátásra áttérő daganatos gyermekek szüleivel folytatott beszélgetésekre (továbbiakban: „palliációs beszélgetés”) vonatkozó sajátosságok, stratégiák és nehézségek feltérképezése céljából strukturált interjúkat készítettünk orvosokkal. Interjúalanyaink $(n=22)$ a Magyar Gyermekonkológiai és Gyermekhematológiai Társaság azon tagjai közül kerültek ki, akik magyarországi gyermekonkológiai ellátást végző osztályokon dolgoznak orvosként (40 fö), és akik előzetes kör-e-mailt követő személyes megkeresésünk után vállalták a kutatásunkban való részvételt. A kis elemszámon végzett strukturált (standardizált) interjú módszere megfelel a feltáró jellegü, kvalitatív kutatások kritériumainak [12, 13]. A kutatásra vonatkozó etikai engedély száma: SE TUKEB: 96/2016.

Az orvosokkal készült interjúkat Budapesten és vidéki központokban 2016. szeptember és 2017. február között ugyanaz a személy vette fel. Az interjúk a következő intézményekben készültek: Semmelweis Egyetem, II. Sz. Gyermekgyógyászati Klinika (6 fó), Szegedi Egyetem ( 5 fó), Pécsi Egyetem (3 fô), Borsod-Abaúj-Zemplén Megyei Kórház, Gyermek-egészségügyi Központ, Miskolc (3 fö), Debreceni Egyetem (2 fó), Markusovszky Egyetemi Oktatókórház, Szombathely (1 fő), Egyesített Szent István és Szent László Kórház, Budapest (1 fö), Tábitha Ház, Törökbálint (1 fö).

A diktafonnal rögzített strukturált interjúk átlagosan 40 percet vettek igénybe és 14 kérdésből álltak. A kérdések a következő témákra terjedtek ki: a palliációra való áttérés beszélgetésének időzítése (kód: 1); egyedül vagy teamben való lebonyolítása (kód: 2); használandó és el- 
kerülendő szavak (kód: 3); annak időzítése, hogy a szülőket felkészítse a gyermek közelgő halálára, specifikus lezajlására (kód: 4); a hospice-ellátás lehetőségének közlése (kód: 5 ); az otthoni és kórházi végstádium mellett szóló érvek (kód: 6); tanácsok a családi feszültség csökkentésére (kód: 7); a testvérek beszélgetésbe való bevonása vagy kihagyása (kód: 8); a gyermek haláltudatának verbális és nonverbális jelei (kód: 9); a szülő kezelési elképzeléseiről való kommunikáció (kód: 10); orvos által javasolt komplementer, nem gyógyszeres kezelések (kód: 11); fájdalomcsillapítási módszerek (kód: 12); az életidő meghosszabbítását szolgáló daganatellenes kezelések alkalmazása (kód: 13); az orvos támogatása a gyermek gyógyszerkutatásban való részvételére (kód: 14).

Az elemzés első fázisában, a felvett interjúk szó szerinti legépelése után, a kész interjúanyagokat szisztematikus narratívaelemzés [14] alá vetettük. Első lépésként az Atlas.ti 6.0 szoftver [15] segítségével kezdetleges kódolást végeztünk, és az összes interjúszöveget a 14 kérdés mentén kategorizáltuk (kód: 1-14). A 14 kérdést az elemzés további fázisaiban végig külön kezeltük. A kezdetleges kódolást követően két szerző egymástól függetlenül az interjúk teljes szövegén, sorról sorra történő szabad kódolást végzett. A szabad kódolás után kérdésenként egyeztettük a kialakult kódrendszert.

Az elemzés második fázisában, ismét külön-külön dolgozva, a hasonló narratívaelemeket dinamikus alkategóriákba rendeztük. Ezután következett az alkódok egyeztetése, majd absztrakció révén kialakítottuk a fó kódokat. A narratívákon alapuló, induktív módon [16] kialakított fö kódokat a cikk másik két szerzője jóváhagyta.

A harmadik fázisban a korábbi fázisokban létrehozott interjúkérdésenkénti kódrendszert a négy szerző együtt összevetette, és az Atlas.ti 6.0 szoftver segítségével mindegyik kérdés kapcsán az inger-válasz-összevethetőség elvére alapozva [12] összehasonlító elemzést végzett.

Jelen cikkben - a palliatív áttérés körülményeire fókuszálva - az első három kérdés eredményét részletezzük, amelyek a következők: „A betegség folyamatában mikor tartja fontosnak a beszélgetést a kizárólag palliatív kezelésre való áttérésről?” (kód: 1); „A beszélgetést szereti-e a szülőkkel egyedül vagy pszichológus jelenlétében folytatni? Melyek az előnyei vagy hátrányai, ha a pszichológus is jelen van?” (kód: 2); „Milyen szavakat használ a mondandó tudatosítása érdekében? Vannak szavak, amelyek használatát igyekszik elkerülni?” (kód: 3 ).

A részletezett kérdésekre vonatkozó kódrendszer a következőképpen épül fel:

Kód 1 (a palliációs beszélgetés időzítése):

1.1. Egyszeri közlés. (1.1.1.: Diagnóziskor. 1.1.2.: Kuratív kezelés végén.)

1.2. Fokozatos közlés.

Kód 2 (team jelenléte: orvos, pszichológus és/vagy lelki gondozó és/vagy szociális munkás):

2.1. Egyedül.

2.2. Késleltetett team. (2.2.1.: Plusz egy orvos.)
2.3. Team. (2.3.1.: Plusz egy orvos.)

Kód 3 (szóhasználat):

3.1. Alkalmazott szavak. (3.1.1.: Egyértelmúség. 3.1.2.: Önvédelem/Empátia. 3.1.3.: Halál.)

3.2. Elkerült szavak. (3.2.1.: Idegen szavak. 3.2.2.: Hátralévő idő. 3.2.3.: Rák. 3.2.4.: Halál.)

3.3. Nem tudott válaszolni.

$\mathrm{Az}$ eredményeink alátámasztására szolgáló idézeteket a szövegben dölt betüvel szedve közöljük.

\section{Eredmények}

A 22 interjúalanyból 14 nő $(63,6 \%)$ és nyolc férfi (36,7\%), átlagéletkoruk 42,68 év (SD $\pm 9,39)$. A válaszadók közül nyolc fó Budapesten, 14 fó vidéken dolgozik. A minta szakterületi megoszlását tekintve két fó rezidens, két fó neurológus szakvizsgával, hat fó gyermekgyógyász szakvizsgával és 12 fő onkológus és/vagy hematológus szakvizsgával rendelkezik.

Az alábbiakban az eredményeket a kérdések sorrendjében mutatjuk be.

\section{A palliációs beszélgetés idōzitése}

Kutatásunk során a megkérdezett orvosok által preferált két időpont a palliációs beszélgetésre a diagnózis közlése (kód: 1.1.1.; $\mathrm{n}=1$ ) és a kuratív terápia abbahagyása (kód: 1.1.2.; $\mathrm{n}=21$ ). Eredményeink alapján azt tapasztaltuk, hogy az orvosok többsége $(\mathrm{n}=2 \mathrm{l})$ a palliációt az életvégi ellátással tartja egyenlőnek. Elmondásuk alapján a kuratív kezelések sikertelensége után váltanak palliációra, mintha addig nem lett volna jelen: „tehát a palliativ áttérésről való beszélgetéskor” (22. számú interjú). Egy másik interjúban megfogalmazódott, hogy a palliatív ellátás középpontjában a terminális állapotú gyermek ellátása áll: „És hogy létezik palliáció, és az arról szól, hogy meg fog halni, de addig mennyi és milyen minóségú élet legyen, erre vannak megoldások” (5. számú interjú). Ez a szemléletmód alapvetően meghatározza a palliációról való beszélgetés időzítését: „A palliatín ellátásról akkor kell elo"ször a szülövel beszélni, amikor úgy tünik, a betegséget nem tudjuk meggyógyítani”(18. számú interjú). Tehát a palliatív kezelés lehetőségét az orvosok addig nem tudatják az érintett családdal, amíg nem biztosak benne, hogy minden elérhető gyógyító terápia sikertelen. Egészen addig csak a kuratív célú terápiára fókuszálnak a kommunikációban is.

$\mathrm{Az}$ eddig ismertetett kommunikációs módok közös jellemzője az egyszeri információközlés (kód: 1.1.). Azonban az interjúk felében elhangzott, hogy fokozatosan végzik a család felkészítését (kód: 1.2.). előzetes beszélgetésekkel, utalásokkal, hogy ne érje majd akkora sokként a szülőket az információ és hogy csökkentsék az érzelmileg megterhelő információ újszerűségét és ezáltal a hatását. A palliációs beszélgetés időzítése kapcsán a 22 válaszadó közül 10 fő (nő $\mathrm{n}=7$ ) a fokozatos információközlés kommunikációs stratégiáját preferálta. 


\section{Beszélgetés - egyedül vagy teamben?}

A palliatív szemlélet megnyilvánul a gyermek körüli multidiszciplináris team szervezettségében is. Minden hazai gyermekonkológiai központban elérhető pszichológus és/vagy lelki gondozó, aki általában a diagnózistól a család mellett van, és bizalmi kapcsolatot alakít ki velük. Ennek a bizalmi viszonynak a fontossága felértékelődik a palliációs beszélgetés kritikus szituációjában. Kutatási eredményeink szerint azonban nem minden esetben zajlik teamben ez a beszélgetés, és megoszlik a vélemény a team fontosságáról ebben a helyzetben. Az általunk megkérdezett orvosok válaszaiból három attitűdöt különítettünk el: a beszélgetés lefolytatása egyedül (kód: 2.1.; $\mathrm{n}=2$ ), késleltetett teammel (kód: 2.2.; n = 2) vagy teamben (kód: 2.3.; n = 18).

Azok a válaszadók, akik a palliációs beszélgetésen egyedül kívánnak lenni a családdal, úgy vélik, hogy: „Minden orvos legyen kicsit pszichológus is, hozzáállás kérdése” (15. számú interjú). Az effajta orvosszerepet képviselő két interjúalany szerint a pszichológus „túl elméleti szemszögből közeliti meg a szituációt” (9. számú interjú) és orvosként „négyszemközt könnyebb közölni a szülövel, ők is igénylik az intimitást ezen a beszélgetésen” (9. számú interjú).

További két fó hasonlóan egyedül szeret lenni ebben a helyzetben: úgy gondolják, ezt kívánja meg a bensőséges kapcsolat a szülőkkel. Azonban ezeknél a válaszadóknál elhangzott a pszichológus kiemelt szerepe, aki rögtön ez után a beszélgetés után külön foglalkozik a szülőkkel. Ezt a kommunikációs stratégiát késleltetett teamnek neveztük el. A közlést megelőzően minden esetben összeül az oncoteam, amelynek a pszichológus is tagja, így - mivel részt vesz a teammegbeszélésen - lehetősége nyílik a szülőkkel kapcsolatos szakmai stratégiájának megtervezésére. Ez a közlési modell tehát lehetőséget ad külön az orvosoknak és a pszichológusnak is a szülőkkel való meghitt beszélgetésre.

A többi megkérdezett személy $(\mathrm{n}=18)$ igényli pszichológus/lelki gondozó jelenlétét a palliációs beszélgetésen. Azokon az osztályokon, ahol mindkét említett szakember elérhető, eltérő lehet szakmai szempontjuk és stratégiájuk. Ahogy az egyik orvos megfogalmazta: „A lelki gondozónak pedig elsödleges feladata, hogy kisérje a beteget, és elfogadja úgy, abogy van, és minimális beavatkozás történjen” (19. számú interjú). A lelki gondozóval ellentétben a pszichológus más szakmai elképzelésekkel dolgozik. A pszichológus korai bevonása a team munkájába eredményezheti azt, hogy a különböző „krízishelyzetek (például szülői reakció) kapcsán egy későbbi, esetlegesen patológiás gyászreakciót” (19. számú interjú) megelőzzön.

A pszichológus bevonásáról 18 fő jelezte, hogy előnyökkel jár, az orvos és a szülő szempontjából egyaránt. A válaszok alapján a pszichológus jelenléte nemcsak az orvosnak támasz, hanem a szülőknek is. Közülük 11 fó nem fogalmazott meg semmilyen hátrányt a pszichológus jelenlétére vonatkozóan.

Több interjúban elhangzott még egy orvoskolléga jelenlétének preferálása (kód: 2.2.1., 2.3.1.; n = 9), függetlenül a pszichológus jelenlététől. Ez a jelen lévő orvos tanúként is funkcionál, továbbá, ha mindketten részt vesznek a beszélgetésen, a továbbiakban a szülők ugyanazt az információt kapják, így a csapat egységét mutatva a családnak. Ez a stratégia az akadálytalan információáramlást és a belső kohéziót is növelheti, ezáltal elősegítve a közös munkát.

\section{A palliációs beszélgetésen felmeriülo szóhasználat}

Amikor közlik a tényt, hogy a gyermeke nem fog meggyógyulni, a szülőnek - még akkor is, ha lélekben már készült rá - ez olyan sokkos állapot lesz, amiból csak néhány kulcsszóra fog emlékezni a későbbiekben. Tehát a palliációs beszélgetésen zajló kommunikáció sikere a megfelelő szavak használatán is múlik, ezért nagyon fontos érthető, lényegre törő kifejezéseket találni. A fentiek értelmében kiemelt kutatási kérdésünk volt a palliációs beszélgetés alatt tudatosan alkalmazott (kód: 3.1.), illetve elkerült szavak (kód: 3.2.) használata.

A tudatosan használt szavak között három alcsoportot különítettünk el: egyértelmúség (kód: 3.1.1.), önvédelem és empátia (kód: 3.1.2.), valamint a halál (kód: 3.2.3.) (1. ábra).

Az első alcsoportban lévő narratívaelemekben a válaszadók az egyértelmúségre és nyíltságra való törekvésüket hangsúlyozták. Az érthető kifejezések mellett interjúalanyaink törekednek az alapinformációk közlésére, így próbálják a legfontosabb információkat a szülőknek közvetíteni: „A szülönek ez egy új helyzet, addig kezeltük a gyerekét, értheto" volt, hogy odajön, de ez egy új helyzet, és a legalapvetóbb dolgokat is újra meg kell beszélni, mert számára nem egyértelmü" (22. számú interjú).

$\mathrm{Az}$ „önvédelem és empátia” csoportba az alábbi narratívaelemek tartoztak: „mai tudásunkkal nem gyógyítható”, „a palliáció egy másfajta segitség”, „ez a lépés egy csapat döntése” (7., 3., 1. számú interjú). Ezek a narratívaelemek egyrészt utalhatnak egy önvédelmi mechanizmusra az orvosok részéről: nem én gondolom így, hanem ez egy gyógyítócsapatnak a közös tapasztalatokon és egyéb orvosi eredményeken alapuló meglátása. El kell mondaniuk a szülőknek, hogy mindent megtettek a gyermek gyógyulása érdekében, minden lehetséges kezelést kipróbáltak, és ez nem egyéni döntés volt, hanem konzíliumok után, kollégákkal együtt hozott vélemény. Továbbá a kuratív kezelés abbahagyása nem azt jelenti, hogy feladják a küzdelmet a gyermekért, hanem másfajta segítséget akarnak adni neki. Nemcsak az orvos, hanem a szülő megnyugtatása szempontjából is fontos lehet ezeket kimondani.

A legambivalensebb vélemények a „halál”, „meg fog halni” (10. számú interjú) kifejezéssel kapcsolatban 


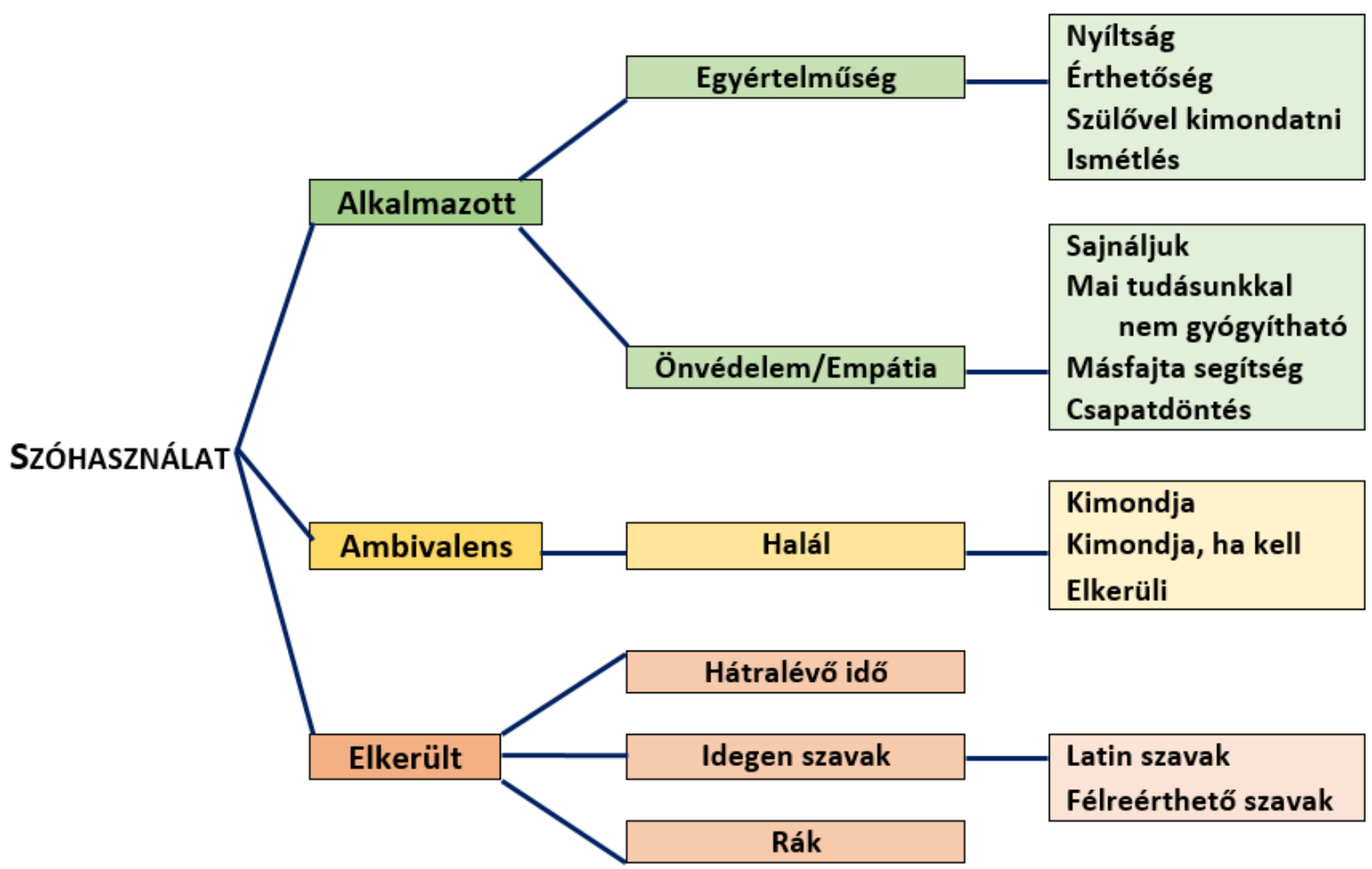

1. ábra

| Szóhasználat a palliációs beszélgetés során

hangzottak el. Egyes interjúalanyok $(n=5)$ tudatosan kimondják a halál szót, nyíltságra és egyértelmüségre törekedve. Véleményük szerint ebben az időszakban már nincs értelme „finomkodni”, kerülgetni szavakat; van, amit ki kell mondani. Hat fö ellentétes nézőpontot képvisel, ők mindenképpen elkerülik ezt a kifejezést, még akkor is, ha a szülő használja, és helyette azt mondják: „el fog menni”; „itt hagy minket”; „elalszik” (20. számú interjú). Ezt azzal indokolják, hogy nekik is nehéz így utalni egy általuk hosszú ideje kezelt gyermekre, akivel már szoros kapcsolat alakult ki.

A halál kifejezéssel kapcsolatban a válaszadók egy harmadik viselkedésmódot is képviselnek. Négy fó preferálta a halál szó elkerülését, de ha a szülő direktben rákérdez, vagy úgy tünik, hogy más szavakkal nem közvetítették sikeresen az információt, akkor az orvos is kimondja. „Legtöbbször a szülo" kimondja, rákérdez: Meg fog halni? [...] És akkor már arra nincs mit mondani. Mit kerülgessem a forró kását?” (17. számú interjú). Tehát van úgy, hogy a szülő - végigjárva a gyógyító kezelés útját - tisztában van azzal, hogy nincs több kuratív terápiás lehetőség, és az orvos részéről is igényli az egyértelmúséget.

$\mathrm{Az}$ interjúalanyok egy része a palliációs beszélgetésben használt vagy elkerült szavakra vonatkozó kérdésre nem tudott az interjúkészítés helyzetében válaszolni (használt: 6 fó, elkerült: 8 fó, nem tudott válaszolni 8 fó) (kód: 3.3.). A téma alulkutatottsága miatt az interjúalanyok többségének még nem tették fel ezt a kérdést, így a rögtönzött válaszadás sokak számára problémát jelen- tett. Emellett számos interjúalany hangsúlyozta, hogy a palliációs beszélgetés szituációja megkívánja az intuíción alapuló improvizatív kommunikációt, valamint az adott pszichoszociális közeghez való dinamikus alkalmazkodást is.

\section{Megbeszélés}

Definíció szerint [2] a palliatív ellátás a diagnózis közlésének időpontjában kezdődik el, ez a szemlélet interjúalanyaink közül csak egy - palliatív ellátással foglalkozó intézményben dolgozó - orvos részéről jelent meg: „Áttérni, azt jelenti, hogy odáig nincs. A palliatín kezelés lebetôsége a diagnózis közlésekor van a szüló és az érintett tudatába bocsátva. És nem áttérek, hanem alkalmazom, a kurativ kezelés mellett a palliativ kezelés lebetösége mindig ott van. A palliativ kezelés lehetóségét tehát az elején hangsúlyozom, és a palliatín team is ott kéne, hogy legyen a gyógyító team mellett” (6. számú interjú).

A korai palliációs beszélgetés a nyugati országokban sokkal elfogadottabb. E kommunikációs stratégia szerint már a diagnózis közlése után elmagyarázzák a szülőnek, mit jelent a palliatív ellátás, mi tartozik bele és hogyan érhetik el. Bizonyos helyeken külön palliációs csapat áll a kórházban rendelkezésre, akik az elején ugyanúgy bemutatkoznak a szülőknek, és a kezelés során végig elérhetőek [17]. Ugyanakkor a korai palliatív ellátás integrációja a gyermekonkológiai ellátás napi gyakorlatába a nyugateurópai országokban továbbra is számos nehézséggel 
küzd. Ezek közé tartozik, hogy a gyógyítószemélyzet az orvos-beteg kapcsolat gyengülését éli meg a korai párhuzamos palliatív ellátócsoport jelenlétével. Sok helyen a palliatív ellátást olyan fajta konzulensi tevékenységnek tekintik, mint egy nefrológiai konzíliumot. A palliatív ellátás korai bevezetése sok esetben a gyermekonkológusok szerint növeli a szülők szorongását [10].

Interjúinkban a palliatív terápiára való áttérésnek a gyógyító lehetőségek kimerülése utáni közlése a jellemző. Felmerült ugyan, hogy bár egy korai beszélgetés jól felkészítheti a szülőt az elkövetkezendő időszakra, és plusztámaszt nyújthat neki, ez nem minden esetben szerencsés. Egy kiváló prognózisú betegség esetében a szülők nem feltétlenül szeretnének másról hallani, csak a kuratív kezelésre akarnak koncentrálni. Ilyenkor pluszemberek bevonása gyengítheti a szülő-orvos kapcsolatot és komplikálhatja az amúgy is felborult családi dinamikát. Azonban egy valószínúleg rossz kimenetelú malignitás esetében segítség lehet a családnak az időbeni felkészítés.

A fokozatos felkészítés szükségességére való utalás az interjúk csaknem felében $(\mathrm{n}=10)$ megjelent. A palliációs beszélgetés itt is a kuratív kezelés végén történik, azonban már korábban történnek utalások ennek lehetőségére. Mindig van egy valószínúbb és egy kevésbé valószínú útja a betegség progressziójának. Habár a diagnózis közlésekor elhangzik már, hogy potenciálisan halálos betegséggel küzd a gyermek, a fokozatos közlésű kommunikációban egy-egy sikertelen terápia után ez újból elhangzik, a fennmaradó lehetséges kuratív kezelések mellett. A fokozatos közlésû kommunikáció esetén, mivel a szülő is végig követi az eseményeket, elképzelhető, hogy nem is az orvos, hanem a szülő fogalmazza meg annak tényét, hogy nem áll több kuratív kezelés lehetőségükre. Ez a lépcsőzetesség segíthet az elfogadásban, erősítheti az orvos és a szülő közti bizalmat, és növelheti a complianceet.

A megkérdezett orvosok más kérdésekre adott válaszokban is utaltak a fokozatosság fontosságára, így kijelenthető, hogy ez a domináns szemlélet közöttük. A fokozatos közlés jobban tükrözi a palliatív nézőpont definíció szerinti alkalmazását, mint az egyszeri közlésú kommunikációs mód.

Az angolszász országokban a korai palliatív ellátás gyakorlati bevezetésének szükségessége annak ellenére elfogadott, hogy gyakorlati kivitelezése jelenleg sok esetben sikertelennek tünik. A helyzet megoldására egyre több helyen merül fel a félelmet keltő „palliatív” ellátócsapat átnevezése megtartott funkciói mellett. Próbálkoznak olyan elnevezésekkel, a palliatív ellátás helyett, hogy „szupportív” ellátás és az ellátócsapatot pedig egyre inkább „szupportív ellátást biztosító csoportként” vagy „életminőség-biztosító csoportként” emlegetik, remélve azt, hogy kevésbé direkt elnevezésekkel elejét lehet venni az ellátással kapcsolatos félreértéseknek [9, 10].

A pszichológus és a lelki gondozó különböző jellegú támogatást biztosíthat a szülő számára, szakmai fókusza miatt a lelki gondozó inkább a vallásos világképpel rendelkezô betegek és hozzátartozóik számára tud célzott segítséget nyújtani. Ugyanakkor szerepe nem feltétlenül redukálható a vallással kapcsolatos tevékenységre. A pszichológus bevonását a beszélgetésekbe az orvosok túlnyomó többsége $(\mathrm{n}=18)$ előnyként értékelte, mivel jelenléte erősítheti az orvost a nehéz helyzetben, másrészt a beszélgetés után visszajelzést tud az orvosnak adni az információközlés sikerére vonatkozóan. Emellett a pszichológus ismeri a lelki folyamatok hátterét, előzetesen fel tudja mérni a gyászreakciót, valamint, mivel más szemszögből közelíti meg a szituációt, közelebb tudja hozni az orvos és a szülők álláspontját egymáshoz. Eredményeink alapján számos esetben hasznosnak bizonyult, hogy a diagnózistól számítva a pszichológus a család mellett van, bizalmi kapcsolatot alakít ki velük, és az orvos számára is hasznos információkat szerez. Akár egy közlési stratégiát is segíthet kidolgozni a beszélgetés előtt, majd utána a család pszichés támogatását („vezetését”) onnan folytathatja, ahol a beszélgetés során tartottak.

Az interjúkból az is kiderült, hogy Magyarországon a gyermekonkológiai gyakorlatban nem használatos a rák szó, helyette a rosszindulatú daganatos betegség kifejezés használatos. Két interjúalany kiemelte azt is: nemkívánatos közölni, hogy a gyermeknek mennyi ideje van hátra. Egyrészt az orvos sem tudja pontosan megmondani, másrészt a szülők elkezdenének visszaszámolni, rettegni, hogy egyre közeledik a „kitűzött” időpont, és ez nyomot hagy a még együtt tölthető idő minőségén. A válaszadók szerint el kell kerülni a félreérthető kifejezéseket, fóleg a tudományos és latin szavakat. Sokan ebból a megfontolásból nem használják a palliatív ellátás kifejezést sem.

A szakirodalom konszenzusa szerint a halál, meghalás szavak használatára vonatkozóan egyértelműen kerülni kellene az „el fog menni”; ,itt hagy minket”; „elalszik” kifejezéseket, mivel akármennyire nehéz kimondani, mégis egyértelmúbb a meghal szó használata. A palliációs beszélgetés - bár lehet intuíción alapuló, ahogy néhány interjúalany hangsúlyozta - önmagunk felkészítését is jelenti: annak átgondolását, hogy miról és hogyan fogunk beszélni a szülőkkel [18].

\section{Következtetés}

A gyermekgyógyászati palliatív ellátás Magyarországon a gyermekonkológiában tekinthető a legfejlettebbnek. Ugyanakkor vizsgálatunk alapján elmondható, hogy a palliatív ellátás bevezetésének időzítésében a korábban megszokott, késleltetett gyakorlat él tovább. A palliatív ellátás bevezetésekor jelen lévő személyek tekintetében és szóhasználatában egyre inkább elterjedőben van a segítő szakemberek minél teljesebb bevonását célzó, a kor elvárásainak megfelelő, jóval direktebb közlési technikák alkalmazása. 
Anyagi támogatás: A közlemény megírása anyagi támogatásban nem részesült.

Szerzöi munkamegosztás: Ny. J.: Az interjúk felvétele, az eredmények értékelése. H. P.: Részvétel a háttérirodalom összegyưjtésében, a tanulmány írásában, szakértői részvétel az eredmények értékelésében. Z. Sz.: Aktív részvétel a módszertani feldolgozásban, az eredmények értékelésében. H. K.: Szakértői részvétel a problémafelvetésben, az eredmények értékelésében és a tanulmány végleges formájának kialakításában. A cikk végleges változatát valamennyi szerző elolvasta és jóváhagyta.

Érdekeltségek: A szerzőknek nincsenek érdekeltségeik.

\section{Irodalom}

[1] Rodriguez-Galindo C, Friedrich P, Alcasabas P, et al. Toward the cure of all children with cancer through collaborative efforts: pediatric oncology as a global challenge. J Clin Oncol. 2015; 33: 3065-3073.

[2] IMPaCCT: Standards for paediatric palliative care in Europe. European Journal of Palliative Care 2007; 14: 109-114. In Hungarian: IMPaCCT. A gyermekgyógyászati palliatív ellátás európai standardjai. Kharón Thanatológiai Szemle 2007; 11: $1-14$.

[3] Knapp C, Woodworth L, Wright M, et al. Pediatric palliative care provision around the world: a systematic review. Pediatr Blood Cancer 2011; 57: 361-368.

[4] Connor SR, Sepulveda MC. (eds.) Global Atlas of palliative care at the end of life. Worldwide Palliative Care Alliance, 2014.

[5] Marston J, Boucher S, Downing J, et al. International Children's Palliative Care Network: working together to stop children's suffering. Eur J Palliative Care 2013; 20: 308-310.

[6] Downing J, Jassal SS, Mathews L. Pediatric pain management in palliative care. Pain Manag. 2015; 5: 23-35.
[7] Benini F, Vecchi R, Orzalesi M. A charter for the rights of the dying child. Lancet 2014; 383: 1547-1548.

[8] Benyó G, Révész RL, Králik I. A Tábitha Gyermekhospice Ház múködésének bemutatása és esetismertetés. [Introduction and a case study of the Tábitha Hospice House for children and young adults.] Kharón Thanatológiai Szemle 2017; 21: 1-15. [Hungarian]

[9] Wentlandt K, Krzyzanowska MK, Swami N, et al. Referral practices of pediatric oncologists to specialized palliative care. Support Care Cancer 2014; 22: 2315-2322.

[10] Dalberg T, Jacob-Files E, Carney PA, et al. Pediatric oncology providers' perceptions of barriers and facilitators to early integration of pediatric palliative care. Pediatr Blood Cancer 2013; 60: $1875-1881$.

[11] Polcz A. Child in front of the gate of death. [Gyermek a halál kapujában.] Pont Kiadó, Budapest, 2001. [Hungarian]

[12] Berg BL. Qualitative research methods for the social sciences. Allyn and Bacon, Boston, 2009.

[13] Babbie E. The practice of social research. Wadsworth, Belmont, CA, 2007.

[14] Timmermans S, Tavory I. Theory construction in qualitative research: from grounded theory to abductive analysis. Sociological Theory 2012; 30: 167-186.

[15] Friese S. ATLAS.ti 7 User Manual. Berlin, 2013.

[16] Thomas DR. A general inductive approach for analyzing qualitative evaluation. Am J Evaluation 2006; 27: 237-246.

[17] Mahmood LA, Casey D, Dolan JG, et al. Feasibility of early palliative care consultation for children with high-risk malignancies. Pediatr Blood Cancer 2016; 63: 1419-1422.

[18] Pilling J. (ed.) Medical communication. [Orvosi kommunikáció.] Medicina Könyvkiadó, Budapest, 2008. [Hungarian]

(Hegedûs Katalin dr., Budapest, Nagyvárad tér 4., 1089 e-mail: hegedus.katalin@med.semmelweis-univ.hu)

"Non qui parum habet, sed qui plus cupit, pauper est." (Seneca) (Nem az a szegény, akinek kevés van, hanem aki többre vágyik.) 